\title{
The Library and the Researcher
}

$\mathrm{E}^{\mathrm{s}}$ VERY JunE throughout the United - States, institutions of learning admit thousands of men and women to the society of previously successful candidates for one academic degree or another. There are but few degree-holders who remember any more of the formula used by the presiding official to confer the degree than "By authority delegated to me-and the rights and privileges -." Amid the joyous flush of achievement, the words "rights and privileges" blend pleasantly into the festive occasion. Under the best circumstances, the mind of the recipient of the B.A., B.S., M.A., M.S., M.D., Ph.D. or whatever degree, has been rigorously trained to precision, analysis, and suspicion-natural enemies of such vagueness as is contained in the "rights and privileges" clause.

And yet this phrase is listened to at commencement after commencement with an understandable and good-natured feeling that the graduate may look forward to perhaps numberless benefits that need not be immediately identified. It is always to be hoped that many graduates comprehend shortly after the June exercises that the above mentioned rights and privileges are not meant to have a ring of the future about them, being in fact things already acquired. Doubtless a number of these men and women come to realize this even before graduation. The rights and privileges inherent in an education are too many and well known to list here. It is, however, appropriate to remark that in college teaching the Ph.D. degree is becoming practically a minimum requirement in the U.S.A. This means that all over the country

Dr. Van Erde is Assistant Professor of Languages, University of Rhode Island. there is an increasing number of teachers who have been through the research discipline required to write a doctoral thesis. More important, for the thesis is usually a very preliminary step in the researcher's career, the fortunate among these teachers have lived for at least three years in an atmosphere of dedication to research. They have seen their professors going quietly about the undertaking of scholarly investigation and bringing the results into the classroom. They have really been a part of the community of scholars (this alone suffices to justify a residence requirement). Here perhaps is the most important privilege to come with the doctorate.

This writer has heard Professor Leo Spitzer, the internationally famed philologist, explain the existence of the History of Ideas Club at Johns Hopkins University as an opportunity for the periodic reunion of the community of scholars on that campus. Of course, any such group comprises a local chapter of a world-wide organization. The members of this organization have in common the curiosity that spurs the mind to research. If, as Voltaire has suggested, the freedom to read books of one's choosing is the privilege of Man, the freedom to conduct research would seem to be the privilege of those who have been specially trained to do it.

The exercise of this freedom is not automatic. In this connection one thinks first of the reckless charges that have been hurled in some quarters in the name of national security at certain members of university faculties. But there is another restraint, which, although not vicious by nature, can be paralyzing in its effect on research, and this is the unavailability of free library facilities. 
The writer can recall returning to the university, from which he holds B.A. and M.A. degrees, while writing a doctoral thesis. He needed to use the library of that important institution to help him in his research. It was rather a shock to be told that if it was desired to use the stacks and borrow books for more than a few days, a charge would be made. More recently another great university at which the writer had once been a graduate student and a graduate assistant on the teaching staff, charged ten dollars to grant borrowing and stack privileges for six months. In another case, a large university has withdrawn borrowing privileges from the faculty members of a nearby institution with meager library facilities. Inquiries among colleagues at various universities suggest that the exclusion of researchers, except those currently connected with the university in question, from free use of the library is becoming common.

This is a serious situation for scholarship. It is not unusual to have to consult more than one great library while working on a particular project (the importance of primary sources, often in manuscript form, does not eliminate secondary sources from the research procedure,) and there are many eager college teachers simply unable to afford the fees now being charged by libraries. And then there is the problem of being unable to borrow from a nearby university with the library adequate for some research activity. It really is not a great consolation to know that one may borrow through interlibrary loan. This is time-consuming and frustrating, as works borrowed under this system must sometimes go back and forth between borrowing and lending libraries more than once before their usefulness to the research project has been exhausted. It is impossible always to foresee the necessity for the reconsultation of previously read items as one meets new problems pertaining to the subject. Furthermore, it is not uncommon to have to pore through work after work in search of a particular point. With normal borrowing arrangements, the researcher could check through many such works in a minimum of time instead of a maximum. Research goes slowly when the researcher must wait for several days after the day that he has chosen items from the library catalog before the interlibrary loan gets them to him.

It is to be feared that, from the undergraduate years on, we tend to look upon libraries as owing us the right to borrow from them. We forget that we are granted borrowing privileges, even from the university in which we are enrolled. Later, when we have had the privilege of living in a community of scholars while at graduate school, we tend to believe that books will always be available to us as they are in the great university. We are wrong to forget that these materials come into our hands solely as a privilege, but insofar as the idea of a community of scholars is valid, we are right to hope that the tools of research will be put at our disposal with a minimum of expense to us and without an inordinate loss of time. And let there be no quarrel about terms here. Who is to say how many obscure researchers there are for every recognized scholar? It is easy for the latter, who sometimes needs only to cross the hall from his office to get into the stacks or even the rare book room, to say that the materials exist, that the researcher has only to prove that he is a scholar and sooner or later he must be invited to join the faculty of the great university. Not many of our seniors in the teaching profession adopt this attitude. The majority recognize the validity of research in general and seek no monopoly. But monopoly there is. The circumstances enumerated above make this inevitable.

The writer of this article is particu- 
larly concerned with an important concomitant of this situation. There is a growing feeling among college teachers that the librarian is the real villain in the story. Nothing could be more unjust and more dangerous to us than this attitude. I personally am in debt to librarians both in this country and abroad. I have seen the great lengths to which the libraries of the University of London, the British Museum and the Public Record Office will go to be helpful. In this country, librarians have without fail been friendly and cooperative. My own university did at least grant me free privileges, given the brevity of my stay; the other great university, finding that I had been able to make the trip but twice during the period for which I paid ten dollars, gave me an additional six months. The university that has withdrawn borrowing privileges from its neighbor's faculty members allows them to come into the stacks any time and read there. These are not isolated instances. Librarians are continuing to give the wonderful cooperation without which research is impossible. It would be a real calamity if members of the teaching profession were to think otherwise. And yet this danger exists.

The librarian's good will is being increasingly challenged by regulations that are in restraint of research. The reason that the dutiful librarian enforcing these regulations looms as a hostile agent is that the necessity behind some of them is not understood. For instance, rising costs have been pleaded as the occasion for the charge for borrowing and stack privileges. Now if the researcher uses a large library, he may use the elevator, and ink has to be consumed to stamp his stack-card and the books that he withdraws. Also there will be some paper work involved in his withdrawals. Is the wear and tear on the books a factor? Without knowing the economic facts of library life, one finds it difficult to be convinced of the necessity of the charge for privileges, based on the grounds stated. Is this just an excuse to discourage use of a library in which even generous collections of books are under the strain of a full demand? Surely no one would deny that the library's prime responsibility is to the university which it serves. Outsiders must come second to the faculty and students of a particular institution. Perhaps the charge ensures the limitation to a minimum of the additional strain on the library from outside borrowers.

What of the library that has withdrawn privileges altogether from the faculties of neighboring colleges? Surely this drastic step has been the result of abuses. Is there a college teacher who has not kept books out for months at a time? Can one justify having anywhere from thirty to sixty books out for long periods? The fact that there may not be a call for such works does not decrease the potential inconvenience to some university borrower, entitled to priority. Have there been cases of misrepresentation of one kind or another? We borrowers know that these abuses have existed, and each one of us has probably been guilty in some way. However, we cannot know the full extent of the librarian's problems.

We know that fees for privileges work a genuine hardship on many of our colleagues; we know that interlibrary loan comprises a valuable but limited service; we feel that research is made to look like a luxury reserved to colleagues on the faculties of the great universities and to others with a goodly amount of spare time and cash. This seems to us a situation incompatible with the ideal of a world community of scholars.

What we do not know are the real reasons behind library policies. The continuing wholehearted assistance of li-

(Continued on page 164) 


\section{The Library and the Researcher}

(Continued from page 106)

brarians suggests that the reasons are overwhelming. The writer entertains few hopes that the situation can be improved. What is fervently to be hoped is that the researcher understand why the librarian has been forced to put certain difficulties in his way. Without this un- derstanding, a growing hostility is inevitable between these two, whose cooperation is a sine qua non of successful research. It is a subject that ought to be aired. Some librarian can do us all a great service by presenting the facts of this matter from his point of view.

\section{Technological Progress}

(Continued from page 123)

With the rapid change around us, it is no longer enough to train our library workers of tomorrow for today's jobs. Observed objectively, the best, most flexible library training possible would be a solid grounding in fundamentals, particularly mathematics and sciences. Fundamentally trained, the library school graduate may thus be able to take advantage of the specialized jobs that develop. Inadequate preparation could mean shortage of personnel to man the machines providing the library service, even as it is today. Today, there are professional routines so close to the clerical routines that even the inadequately trained professional may find placement because the supply is smaller than the demand. In automated libraries this might not be possible.

Librarians are feeling the pinch today for top-caliber personnel. This shortage, which will grow, soon will force additional streamlining of procedures, short cuts in indexing, cataloging, and increased salaries. Personnel shortages will force the first automation. And before automation becomes a significant part of library procedures and routines, librarians and library schools must face up to the problems of preparing within their own ranks sufficient technically trained people able to perpetuate the advances made and to add others.

It is very necessary that library schools be well aware of developments in the field of automation-where they can be applied, and where they may be improved. Most librarians, however, are unaware of the magnitude and complexity of the problem of switching from present-day libraries even to partially automated libraries. The significance of scientific advances, particularly in the field of electronics, requires re-emphasizing and re-examination of the basic principles of librarianship from which the every day struggle for space, personnel, and money has distracted us.

If librarians do not learn to extend their techniques and develop the new techniques required, other agencies, or new professions, will be created to do the job. If librarians restrict their activities to fit within the present framework and structure of librarianship, they will fail in their obligations to society. 